\title{
Elites in Competition and the Reorganization of Power: The Case of Brazil
}

\author{
Cristina Gomes \\ Population and Development, Latin-American Faculty of Social Sciences, FLACSO Mexico, Mexico City, Mexico \\ Email: cristinagomesmx@gmail.com
}

How to cite this paper: Gomes, C. (2019). Elites in Competition and the Reorganization of Power: The Case of Brazil. Sociology Mind, 9, 17-41.

https://doi.org/10.4236/sm.2019.91002

Received: October 3, 2018

Accepted: November 3, 2018

Published: November 6, 2018

Copyright $\odot 2019$ by author and Scientific Research Publishing Inc. This work is licensed under the Creative Commons Attribution International License (CC BY 4.0).

http://creativecommons.org/licenses/by/4.0/

\begin{abstract}
This article describes the formation of the traditional elite of Brazil from the colonial period, and the main ruptures affecting the republic during short democratic periods in which changes were observed in the composition of their elite. The most recent change is historically contextualized by the formation of a new elite, in the form of the governments of Lula da Silva and Dilma Rousseff, who were never part of the political-military-hereditary lineage of traditional elites. This was the scenario of the 2014 elections and the impeachment that once again broke away from the democratic system. The historical practices of the traditional elite of Brazil showed themselves to be caught in a vicious circle around the coup d'état to return to power, confronting the responses of the new progressive elite that had resulted from elections during the short periods of democracy. A qualitative methodology of bibliographic review is applied for the construction of the conceptual and analytical framework, and the collection of information from the media for recent facts has still been little analyzed with content analysis, and is complemented with two interviews with people who occupied high government posts, both before and during the coup. The results indicate that the new government elite undervalued the process of financial globalization and promoted the strengthening of representatives of international networks and their entry into the decision-making process, where they formed parallel command structures and networks contrary to government decisions and facilitated the rupture of democracy.
\end{abstract}

\section{Keywords}

Elites, Competence, Democracy, Coup of State, Dictatorship, Impeachment, Oligarchy

\section{Introduction}

Elite theory focuses on how a small number of elite groups concentrate and dis- 
pute power in specific societies and historic periods and how the elite actions in political, economic and status power relationships shape both the past and the future. Pareto, Mosca, Weber and Michels are the originators of elite theory; these authors describe how this small minority creates and adopts rules, means and practices in order to continue controlling power, co-opting a few non-elite members, and assuming the principal role as political and social actors. Elites include top politicians, heads of state agencies, business and managements leaders, among others, who dominate societies through the bureaucratization of power (Pakulski, 2018; Lopez, 2013). Milner (2015) analyses different types of politic elites who control the state, executive offices and organizations, and the economic markets in order to establish and maintain liberal democracies through competition and agreements on the "rules of the game" and for selecting those who control the government.

In this article, Pakunski and Milner's perspectives of the elite are adopted to analyze the electoral democracy in Brazil focusing on the formation of the traditional elite group that has historically controlled the state, in order to understand the recent change, when members of non-elite assumed power for 13 years until a controversial impeachment. The main hypothesis is that, for four centuries, Brazilian traditional elites controlled the State through authoritarian regimes, considering the Brazilian population as non-citizens. This hypothesis relies on Ribeiro's (1976) definition of the origin of the Brazilian society, as being similar to a patriciate of slaveholders of the Roman Empire, where non-elites were considered non-citizens and need to be instructed and controlled by the elites. That definition is close to the Pareto's perspective: Brazilian elites historically act as a political minority that substitutes democracy by authoritarian systems, according to their self perception of "superiority", compared to a non-elite, which would have an "inferior human quality".

This article describes these changes in modes of domination and reproduction from the colonial period to the Republic, the power of the traditional elites and their ability to transform and reproduce themselves continually until the $20^{\text {th }}$ Century (through bloodlines), and elite's family heirs graduated in European universities, with a long trajectory leading to control power in the highest political positions in the State, as military leaders, judges and other secondary positions in bureaucracy, and as new financial and export trade businessmen who control the economic market.

How does this formation, based on slavery and latifundia, underpin the feeling of superiority of the heirs of family elite with their presumed special qualities to manage and control the majority of the Brazilian population? Non-elite Brazilians are described in literature and media as "bestialized"-irrational people that do not deserve to be recognized as citizens-(Brazil does not have people, Carvalho, 2003). Ignoring the Brazilian population, denying its existence, and considering them as "inferior people with insignificant quality" (Lipset, 1967), generates a feeling of low self-esteem which, in turn, prevents or delays the rec- 
ognition of citizenship, decisions, movements and rights of the large majority of the population-the non-elite.

This idea legitimizes recurrent authoritarian regimes and elite responses to popular demands and movements, based mainly on the use of the force by the State and recurrent coups, leading to long periods of dictatorship with short lapses of restricted and tutored democracy, maintaining a permanent control on the "inferior" population.

The article presents the results of the analysis in three parts, corresponding to historical periods. The first part describes the formation and reproduction of the traditional elites in Brazil from the colonial period, the war-free independence, the empire, to the first republican period, or "RepublicaVelha". The analysis focuses on the predominance of the oligarchic elites of slave-farming landowners and the emergence of an urban merchant and finance elite. The republican period started with a coup of State organized by the oligarchic slave-farming landowner elites and senior military commanders, as a counter-reaction to the abolition of slavery established by an emperor decision, against the interests of the oligarchy.

After the regime rupture in 1930, in the first years of Vargas dictatorship, for the first time, elite oligarchies lost political control. However, there was no elite renovation. Vargas gradually exchanged political groups at local level of government, and maintained the political oligarchy, his indications for high political positions combined a gradual absorption of secondary traditional oligarchy elites, allied groups and later irreconcilably enemies. Oligarchy elites participated in Vargas dictatorship and led the creation and the expansion of their new elite political parties (Codato, 2015: p. 323). Therefore, in Brazil, it wasn't possible to apply the concept of "circulation of the elite" during that period, as it had been in Western Europe, since this concept presumes the end of the exclusive aristocracy power and a turnover of new parliamentarians, and the entry and exit of non-elite individuals in political representation (Bottomore, 1995), a characteristic that continued to be non-existent in Brazil latter half of the $20^{\text {th }}$ Century.

The second part discusses how the short period of democracy was interrupted by a military coup d'état. There was a reorganization of the old oligarchic elites, at a time of the development of the new model of capitalist expansion, which dominated the financing of the economy, communication technologies (soft power) and the military and judicial apparatus. The concentration on the economy generated a new composition of business elites, the destruction of failing companies and new winning oligopolistic elites were consolidated in new business monopolies.

In Brazil and Latin America, transformations in the composition of the elites in power did not mean a break with the previous structure (since the archaic elitist structures were never eliminated) but maintained the previous elites' presence in the political scene. After 21 years of military dictatorship Brazil has a 
consolidated military and judicial elite as a legacy, organized into a powerful and influential lobby, that does not accept the participation of other sectors of the population (Missiato, 2011).

In the third part, the most recent changes are historically contextualized: the movements of non-elites, the return of democracy, and two presidential impeachments-the neoliberal governments of Collor de Melo, Itamar Franco and Fernando Henrique Cardoso, traditional heirs of traditional oligarchy elites, and the governments of a new elite (Lula da Silva and Dilma Rousseff) who were never part of the political-military bloodline of traditional elites. This was the scenario of the 2014 elections and the impeachment, breaking the democratic system and the first real process of elite circulation. The historical practices of the traditional elites of Brazil showed their recursive nature, circling around the coup d'état to return to power, and confronting the responses of the new progressive elites that had resulted from elections in the short spaces of democracy.

The emergence of a new elite in political power, the governments of Lula da Silva and Dilma Rousseff, members of non-elite, explains the main political reactions to this new process of elite circulation in the 2014 elections and the Rousseff's impeachment that, once again, broke away from the democratic system. The historical practices of the traditional elite of Brazil showed themselves to be caught in a vicious circle around the coup d'état to return to power, since oligarchy has no candidates able to win elections, and confronting the responses of the new progressive elite that had resulted from elections during the short periods of democracy.

\section{Methods}

The methodology adopted to analyze the elites' alternation in power in Brazil includes a bibliographic revision and an analysis of the information and documents from the media on the historic and recent facts, complemented with two interviews to people who occupied high government posts before and during the coup of State. The method of conventional content analysis was used to code categories of elites, states and grade of authoritarian and democratic regimes, derived directly from the text data. The approach was direct from elite theories analysis followed by relevant information on the elites in historical periods, as guidance for initial codes on political elites and its predominance in each period, continuities and ruptures in democracy, as well as the interpretation of the underlying context (Hsieh \& Shannon, 2005). Two interviews were collected with new elite members, one of them from the media and the other was a telephone interview applied by the author to a former Minister of State. The results indicate that the elite in the government undervalued the process of financial globalization and promoted the strengthening of representatives of international networks and their entry into the decision-making process, where they formed parallel commands and networks contrary to government decisions and facilitated the rupture of democracy, and that new coups of State are increasingly articu- 
lated with transnational power networks.

\section{Results}

\subsection{Brazil and the Formation of its Elites, from Colony to Empire and Republic}

Brazil was a colony of Portugal during the sixteenth to nineteenth centuries. In 1822, it had a war-free independence process, proclaimed by the son of the king of Portugal-D. Pedro I-who abdicated in 1831. However, his son, at only five years old, could not assume the empire's throne; D. Pedro II was tutored by the oligarchic elites of slave-farming latifundia until he was old enough to assume the crown, and he remained king until the end of the empire. Throughout this period, Brazilian society and the political and economic structure functioned in the style of a Roman slave patriarchy (Ribeiro, 1976). Brazil was one of the four last countries in the world-the last in Latin America-to ban the trafficking and slavery of Africans, the most profitable business in the country, which had enriched an emerging urban merchant elite.

Under pressure from Britain, a law ending the slave trade was passed in 1850; the oligarchic elites were progressively forced to adopt free labor and, for that, they imported European, Asian and Syrian-Lebanese workers, initially treating them as semi-slaves (Davatz, 1850). The immigration policy also aimed to "whitewash" or "cleanse the race", replacing the vast majority of the black population, and creating the myth of a "racial democracy" in Brazil (Fernandes, 2008; Schwarcz, 2001).

In 1889, a year after finally abolishing slavery, the entire imperial family was exiled from the country through a military coup that proclaimed Brazil to be a republic. In contrast to the countries of Western Europe and all other countries of America, Brazil's republic began with a military coup, a rebellion of the landlord-slave elites who opposed the end of slavery that had been signed into law by Princess Isabel. This elite rejected the transition to capitalism, industrialization, modern values and the recognition of citizens' rights.

There were then 40 years of an oligarchic republican system (1889-1930); between 1894 and 1930, dominated by the same archaic agricultural elites of the states of Sao Paulo and Minas Gerais, in a pact during which these two oligarchies alternated in power and recruited their members according to family origin and social class, this closed system guaranteed the sovereignty and stability of the state and its institutions (Wedel, 2017; Lipset, 1967; Ribeiro, 1976).

These characteristics of Brazil's traditional elites coincide with the classic perspective of Mosca and Pareto, which define autocratic states, such as the Brazilian slave-owning patriciate, as systems in which a political minority substitutes democracy by being considered to be a bearer of "superiority" whose qualities enable the management of a majority of inferior or insignificant quality (Lipset, 1967).

During the crisis at the beginning of the 20th century, the secondary land- 
holding elites of the north and south of the country allied themselves with the new financial, commercial, military and bureaucratic sectors and organized a military coup, assuming power through a sergeant and son of southern landowners, Getulio Vargas (1930-1945). It was the developmentalist period of industrialization, strengthening the state, institutions and bureaucracy, as well as the first industrialization phase. According to Codato (2015), Vargas governed as a dictator, indicating and substituting gradually political groups at local level, controlling old political purges of the elites; he preserved the political staff while promoted also a partial renovation in the composition of senior management. This author adopt the Gramsci hypothesis of a transformation of the political elite, as a "gradual but continuous absorption, and obtained methods of the active elements arising from allied groups and even of the adversaries and who seemed irreconcilably enemies" (Gramsci, 2002: p. 63, cited by Codato, 2015: p. 322). In this sense, Codato rejects the idea of a co-optation, since co-optation implies a tactical response from de elites in order to contain claims of demand and participation, what didn't happened in the period of Vargas dictatorship.

Although the revolution of 1930 took the power from the traditional elites and closed their political parties, after 1937 some of these elites were reorganized to participate in the dictatorship, and leaded the creation of the new political parties of the states of Sao Paulo, Labor Party Brazilian (PTB) and the Social Democratic Party (PSD), expanded from regional to national parties (Souza, 1976, cited by Codato, 2015: p. 323). And in Vargas period a bureaucratic state rearranged the old oligarchies in the power. Therefore, in Brazil, it isn't possible to apply the concept of "circulation of the elite", as in Western Europe, since this concept presumes the end of the exclusive aristocracy power and the turnover for new parliamentarians, the entry and exit of non-elite individuals in political representation (Bottomore, 1995), a characteristic that continue inexistent in Brazil until the half of the $20^{\text {th }}$ Century.

On the contrary, Western Europe experiences declining in political power of the nobility and an increasing process of professionalization of the politicians from non-elites. Aristocrats of agrarian sector were predominant from 1848 to 1880; but after 1880 lower classes start to participate as political representatives, and the traditional nobility progressively leaves the scene. After 1920, the middle-class, with a high level of education accumulates social and economic background and political experience, assumes political activity and develops high grades of professionalization in the exercise of political power, in an context of increases in the universe of citizens and voters, and the mass parties become complex organizations able to coordinate a sophisticated process of aggregation of interests (Best \& Cotta, 2000).

In his last government, Vargas was elected president (1951-1954). Accused of corruption, although this has not proven even to this day, he committed suicide (D’Araujo, 2001; Freire \& Penna, 2001). Vargas suicide prevented a new coup of State from the same main traditional landowners elites, and it was followed by a 
first short democratic period that saw a growing popular participation of newly organized sectors of workers, bureaucrats and civil society, now diversified with foreign immigrants.

At the end of this period, after the Second War and based on the experiences of Western Europe and the USA, Weber, Michels and Mills develop critical perspectives on the classical elite theories of Mosca and Pareto. The new concept of "power elites" describes how members of the elites assume the positions of society's high command, and control, operate and influence political and economic issues in a triangle of power-the military leadership, the state and the economic corporations and how they alternate between themselves. These three domains expand, centralize and coordinate more and more (Mills, 1956; Wedel, 2017; Davis \& Williams, 2017). This perspective is according to changes in elites in Brazil in this entire article.

\subsection{Ten Years of Short Democracy and 21 Years of Military Dictatorship}

The next phase of the Cold War (1954-1964) was a short democratic period that saw a growing popular participation of newly organized sectors of workers and civil society-in addition to state bureaucrats-that had been strengthened during the previous period. The period's three presidents tried to implement developmental strategies and social policies. However, only one-Juscelino Kubistchek-managed to conclude his presidential term andhe consolidated the industrialization of the country with international financing, which exacerbated the external debt (Mourão, 2012). The last president-Joao Goulart-was overthrown through a coup by the civilian and military elites, this time in association with the United States, in the context of the USA's policy regarding military dictatorships in Latin America and, at the same time, allowing the armed forces of the USA to assume a leading role in decisions concerning national and international politics (Davis \& Williams, 2017).

After four centuries of empire and a period of alternating power between two regional oligarchic elites (1894 to 1930), the next 114 years of the Republic saw 34 presidents, although only 16 of them were elected by direct vote and only one concluded his entire presidential term ${ }^{1}$. The maximum electoral participation reached until then was $10 \%$ of the total number of voters. The civil-military coup of 1964 consolidated this autocratic system, now commanded by the Brazilian military elite that still continues to influence decisions in the corridors of power up to the present day. The incorporation of transnational capital into the economy was also expanded and the economy concentrated on monopolies (Santos, 2014; Cesário, 2016). For example, once all the other communications companies closed down or went bankrupt due to the censorship imposed by the military dictatorship, just four families appropriated all of Brazil's communications

\footnotetext{
${ }^{1}$ Throughout the republican period, since 1889 , there were 40 presidents, 18 elected by direct vote,
} of these, 5 completed the mandate. 
business.

As in most other countries in Latin America and Europe, these transformations in the composition of the elites in power did not mean a break with the previous structure (since the archaic elitist structures were never eliminated) but maintained the previous elites in the political scene, even when the new elites and emerging influence groups, bureaucrats and bachelors, benefited from social ascension during the previous developmental governments. The 21 years of military dictatorship left a consolidated military and judicial elite as a legacy, now organized into a powerful and influential lobby, with exclusivity to make decisions on public security and the national interest, not accepting the participation of other sectors of the population in these issues, even after democracy had been restored (Missiato, 2011).

In the passage from dictatorship to democracy, there was a reorganization of the old oligarchic elites, at a time of development of the new model of expansion of capitalism, which dominated the financing of the economy, communication technologies (soft power) and the military and judicial apparatus. In Brazil, this process of concentration of the economy generated a new composition of business elites, the destruction of failing companies and new winning oligopolistic elites were consolidated in new business monopolies².

Globalization, deregulation, privatization, free trade agreements and the financialization of capital markets began to exercise control or influence over capital flows, and transnational networks today handle values much greater than those controlled by the states. The elites of global financial markets also came to exercise power over national political and economic institutions and decisions, fragmenting governments and key decision-making institutions (Davis \& Williams, 2017).

New relationships between state and capital were established. The state transferred a large part of its functions to the private sector and multiplied decentralized power structures, creating new positions to be occupied by multiple new corporate actors and representatives of international market interests. There was a professionalization of the parties and a de-politicization of decisions, the experienced senior politicians giving up their political decisions and the operational power in favor of specialists and external institutions, which are not obliged to submit accounts. The elites were struggling to direct state decisions, but now the democratic channels of the state could queue-jump, without so much "waiting in

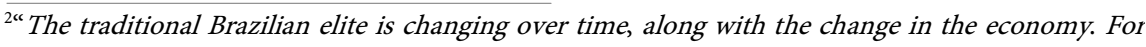
this, the concentration of the financial sector, of the retail sector, of the agricultural sector, has been fundamental, all these sectors were very concentrated. And the traditional groups that predominated at the beginning of the last century, until the $70 \mathrm{~s}$, lost economic and political strength. The traditional business elite was already in a process of change, not structural, but of emerging groups and groups in decline. The national financial sector and the national retail sector have lost strength. In the agricultural sector, the emerging exports of latifundia, soybean, cotton and meat groups appeared. And the decadents were coffee, oranges, sugar and alcohol... national airline companies leave the market, and the new ones enter". Ricardo Berzoini, former Minister at Lula and Rousseff governments. 
line". That further divided participation and democratic political leadership, which had been losing power for decades (Wedel, 2017; Davis \& Williams, 2017). It was thus that the military elites installed themselves in power in the United States and in Latin America, without having to give any account for their actions.

In Brazil, these tendencies of globalization, trans-nationalization of companies and power elites have been observed since the last decade of the military dictatorship, when foreign groups acquired a large portion of the banks and companies and entered the national market, concentrating and denationalizing the economy, weakening the interest and capacity of national elites, and increasing the capacity of trans-nationalized elites to interfere in the political and economic decisions of the state.

\subsection{Mass Democracy: Popular Movements and Competition among Elites and Non-Elites}

In the last period of the military dictatorship, the regime indirectly chose the first civilian president-Tancredo Nieves, who died soon after, and was succeeded by his vice-president, José Sarney (1985-1990), a leader of the secondary oligarchy, of the state of Maranhao, and who had been governor and senator for the same state. In 1980, his party was created, and endorsed by the military, which added to the center political elites-the Brazilian Democratic Movement, MDB, the largest party, which today has more than 2 million members. The Sarney government was conducted under the supervision of the military (Missiato, 2011; Saez, 2004).

In this period, the social movements, which were organizing themselves in the protests during the dictatorship, consolidated and expanded; in particular, the new elites of union leaders, formally workers, from which Lula da Silva emerged, gave rise to the Single Workers "Central and the Workers" Party in 1980, as well as hundreds of local movements and leaders, from indigenous and rubber gatherers in the Amazon to students and professors in universities to intellectuals, liberal professionals and communities in metropolitan regions. Also the business sector, including the transnational corporations, which were being suffocated by the economic crises and workers' strikes, was organizing itself into associations that negotiated directly with the unions, establishing alliances between these different sectors of civil society.

These groups and networks of new elites actively participated in the National Constituent Assembly (ANC) that restored democracy, in the definition of the Constitution of 1988, and in the direct elections of 1989. Employers hired professional companies and located political advisory offices in Brasilia, to strengthen relationships and contacts, and to follow the Congress and the Executive

Branch, in order to obtain relevant information and influence the decision-making process of democracy during its formation (Santos, 2014).

The 1988 Constitution restored democracy, human rights, citizenship, direct 
elections, the vote of illiterates and young people aged 16 and 17, and permitted the creation and legalization of new Left-wing parties (Chaia, 2010); The Legislative Power once again assumed the central role in the new constitutional order, as the arena for important political disputes and the decision-making process.

Former Minister Franklin Martins highlights a relevant fact in this process: for the first time Brazil had a mass democracy, which further increases the complexity of the democratic game ${ }^{3}$.

This plurality of actors is also expressed in their greater participation in parliament; the participation of parliamentary lobbyists has increased since 1983. In the 1983-1984 biennium there were 47 registered interest groups in Congress, by 1994-1995 there were already 121 groups, and by 2011-2012 that had multiplied to 1795 groups, an impressive increase in the pluralism of interest groups in political decisions (Santos, 2014).

Many of these new elites do not have previous democratic political experience, since they were formed during the 21 years of dictatorship, and they had had to use the lobby to systematically represent their interests. This has high costs and demands an increasing mobilization of resources. The increase of pluralism and of professionalization in the decision-making process displaces the oligopolistic and military elite from their previous comfort-zone, when they were the only decision-making agents; an increasingly judicious observation of the state was generated by the whole of civil society, provoking reactions from traditional elites. In order to limit the participation of the new elites of union and popular leaders in the center of political decisions, party fragmentation in parliament was promoted ${ }^{4}$.

\footnotetext{
3"Only after the 1988 constitution did Brazil become a mass democracy. In 1930, in the last elections of the old republic, only $5 \%$ of Brazilians with the right to vote voted; at the end of the Vargas period, $13 \%$ voted, thanks to women right to vote. This percentage increased to $17 \%$ before the civil-military coup of 1964. In the re-democratization the vote of the illiterate was approved; then there was a surge in votes cast to $48 \%$ in the first elections, which increased to $56 \%$ of the population in the second round of the elections, when Lula and Dilma Rousseff were elected. This campaign must speak for all sectors, not only for the coffee, milk, and cocoa oligarchs-we must speak for all, we must deal with the big social problems, the greatest of which is the enormous social injustice and existing discrimination... and strong inequalities... deconstructing the conservative discourse, causing elites difficulty in disputing and forming a majoritarian discourse in society." Franklin Martins, former minister of Lula da Silva government

"'That's why (mass democracy) they created a way to love the executive, to have a legislative increasingly pulverized, increasingly smaller, more 'comparable'. Another important fact of the constituent of $1988, \ldots$ there was an extremely efficient electoral system for president, and the people voted and, going into a second round, alliances were made in full view of the people, who had to legitimize them if that was what they in fact wanted (or not) and the people had conditions to change later. In contrast, the proportional elections for the chambers of municipal representatives, legislative assemblies, chambers of deputies, and senate were totally opaque-the people did not know who they were voting for... This was aggravated later, when the Federal Supreme Court, already improperly interfering in the legislature, defined that the television time and the percentage of the party fund belonged to the candidate, to the deputy, and not to the party... There were already many political parties, twelve or thirteen, and the number of parties leapt to thirty. That indicates that there was patronage. That is corporatism carried to its ultimate consequences. Why did they do it? That was the way they found to try to control an executive that they felt increasingly difficult to win through direct elections. It was the counter-weight." Franklin Martins.
} 
Faced with this fragmentation of the parties in the 1989 elections, governments went on to organize coalitions between parties to support their policies. That demanded from the Executive a coordinated effort to make agreements with Congress and with all the groups of old and new elites.

\subsubsection{The 1990 Elections and the Deposition of the First Elected President in Democracy}

The first elections were held in 1990, won by Fernando Collor de Melo (1990-1992) of the National Reconstruction Party-PRN (1989). Originally from a family of the oligarchic elite of the northeast, he was supported by all the major groups of political, economic and media elites, which had been transformed into family monopolies during the dictatorship. Previously, Collor de Melo was a municipal representative, federal deputy and governor. He named his cousin as minister of finance and another cousin as minister of the Supreme Federal Court. His government gave continuity to the previous hyperinflation and adopted liberal policies, enforcing the first confiscation of account holder resources in the country (Bresser-Pereira, 1992). It was successful in controlling inflation in the beginning, but later the economy plunged into a deep crisis, generating hardship and great dissatisfaction. Accused of corruption, he resigned before suffering impeachment and, a few years later, he was declared innocent by the judiciary.

The tensions and institutional limitations of the newly democratized state and of a population born into democracy, showed the immaturity of the new and old elites to deal with coalitions, with political agreements between interest groups, with the new demands of civil society and of government bureaucrats in short to deal with mass democracy and with a civil society increasingly mobilized and complex, with multiple tensions and demands, in a hybrid system that must serve elitist, pluralist and corporatist interests simultaneously.

In this new and wide field of interests, the Executive was forced to negotiate and establish a coalition of elites, parties and society groups, as well as go through decrees, provisional measures, emergency requests, etc.; Collor de Melo did not manage to dominate the legislative agenda, which was controlled by particularist and parochial interest groups of the corporatist and regionalist model of negotiation, before reaching a non-negotiable crisis and, finally, tendering his resignation.

He was replaced by Itamar Franco (1992-1993), the vice-president, representing the oligarchy of the state of Minas Gerais, and who had experience as a municipal representative, senator and governor. Franco managed to rescue the government from the previous crisis, creating the Real Plan, of macroeconomic adjustment, which was continued by the next president.

\subsubsection{Fernando Henrique Cardoso: Macroeconomic Adjustment and Privatizations}

Fernando Henrique Cardoso-FHC (1994-2003) had been both a senator and a minister, and had participated in the founding of the Brazilian Social Democracy 
Party-PSDB (1988), for which he was elected. After JK, FHC was the second civilian president in the democratic history of Brazil elected by direct vote and managed to completely fulfill his presidential term without resignation or coup d'état, and was the first president to be re-elected (1998-2002), through a change in the constitution approved by the congress.

FHC appointed various economists, trained in the United States, to key governmental positions. The Washington Consensus and the adjustments to the economy were implemented successfully, drastically controlling hyperinflation, which allowed it to govern with a broad coalition and without facing economic or political crises. His re-election was easily negotiated with all the political and economic elites of which he was a part, and received obeisance; he was a son, grandson and great-grandson of generals of the Empire, his great-grandfather having assumed the presidency and vice-presidency of the country during the Empire and slavery period in addition, FHC was the typical Bachelor with a doctorate degree from the University of Paris. Both titles, that of an heir of the traditional military elites and the academic one granted him a superior status that had been reproduced since colonization, in accordance with the aristocratic values and patrimonialism of the oligarchic elites.

The FHC government obeyed the first phase of the process of broad financialization of the economy, or "new forms of extraction of wealth" that occurred throughout Latin America in the 1990s, with the privatization of state-owned companies, and the review of public resources for institutional investors and private companies. However, it failed to privatize collective pension funds, reforms that led Latin America to a demutualization of insurance companies and the securitization of mortgages and loans, which began to operate with little transparency and obscuration of banking movements and complex derivatives, handling large volumes of money without clear regulations, beyond the control or surveillance of central banks (Wedel, 2017; Davis \& Williams, 2017).

In Brazil, the process of trans-nationalization and globalization of the economy, with the privatization of the national telephone and mining companies, received strong criticism from nationalist sectors and the trade union and social movements, as well as being accused of irregularities and corruption, as had happened in other Latin American countries. However, there were never any investigations or punishment of those responsible, as was the case of Fujimori in Peru, Ménen in Argentina, Salinas de Gortari in Mexico, among other former presidents.

The new transnational actors came to dominate power in different areas; financial, technological and the military were part of the process of globalization and the strengthening of global post-war authorities (International Monetary Fund-IMF, World Bank, etc.) occurred with the increase in digital technology, communication and transport demands of neoliberalism. At the same time, the new economic elites were strengthened, profitable positions were multiplied in ${ }^{5}$ Doleiros are the economic agents that handle currency exchange. 
high and medium positions of the state and the market, which were now occupied by specialists, consultants, lobbyists, doleiros ${ }^{5}$ and other intermediaries representing the elites, now interconnected, and also with the new global and national authorities (Wedel, 2017).

The networks of high school graduates, relatives and friends of the traditional political elites of Brazil were to benefit from this process, becoming intermediaries in the transnational system, employees specialized in legal knowledge, technical, accounting, lobbying and others, multiplying the types and number of elites (Davis \& Williams, 2017: pp. 17-18).

In the dictatorships, formational leaders were imported from the United States, for example, ambassadors and US military commanders instructed the militaries of the region. In a neoliberal democracy, this mechanism was replaced by the hiring of advisers from international organizations, at very high cost, to guide the decision makers. Subsequently, cadres of national elites were formed abroad, mainly in the USA and the UK, which, upon their return, implemented the Washington Consensus measures and the interests of transnational financial and business elites in their countries of origin (Babb, 2001). This was the case of the economists who assumed the highest command of the FHC governments: Andre Lara Resende, Edmar Bacha, Pedro Malan, Gustavo Franco, Arida Persio, Bresser Pereira, Celso Lafer (Belieiro, 2008).

Latin American elites, still imbued with traditional family archaic values, used privatization processes not only to benefit relatives and friends economically, but also to position their networks of relatives and collaborators at the top of the financial markets and transnational corporations.

However, as in other countries such as Asia, Russia and Latin America, macroeconomic adjustment plans and state privatizations ended in deep recession and low growth (2.2\% in 2002), devaluation of the currency, reduction in purchasing power of the population, a record increase in unemployment rates (from $6 \%$ in 1995 to $9.1 \%$ in 2002), and an increase in poverty and external debt (World Bank, 2016). A multiplicity of social policies with low coverage and impact did not mitigate the serious effects of the economic crisis, leading to the loss of popular and business support that FHC had gained for seven consecutive years. Its political, aristocratic and intellectual image was worn away with the serious crisis of its second period (1998-2002), and the traditional political elites, many of them in the PMDB-a typical party of regional oligarchs-abandoned the coalition government base.

During the eight years of FHC's presidency, it became evident, through various scandals, that the political-partisan co-optation of delegates of the Federal Police and members of the Public Ministry by the party of the former president, PSDB, introduced a phase of politicization of the organs of investigation and justice in order to protect their party and weaken political opponents. These organs and corporations of investigation and justice treated some of their members like political candidates and participated actively in Congress. Cesario 
(2016) demonstrates that the organs that came to assume an increasing role in the political process were the Federal Police (PF), the Brazilian Intelligence Agency (ABIn), the Controladoria-Geral da União (CGU), which also used parliament as a theater for relevant political dispute.

Therefore, in the democratic period, the growing pluralism of interests promoted greater competition to influence the decisions of political elites, both in the executive and legislative areas, reflecting a huge diversification of actors and interest groups and greater competition, in order to influence presidential and legislative agendas, decisions and elections. But now a third power got involved among the political elites-the judiciary (until then protected by its constitutional role of impartiality).

The process of financialization and the privatization of services and goods began in the 60s and 70s in Mexico and the USA, and it was already known that they generated profound changes in state-capital relations, new forms of value extraction, new insecurities and resources for elites and changes in the role of intermediary elites, specialists and lobbyists (Davis \& Williams, 2017). Financial activity came to influence politicians and political discourse. Economists influenced by the Chicago school and the like brought deregulation to the whole world, infiltrating state institutions and disciplining the state elites from Denmark to Korea and to Mexico (Babb, 2001).

The popular dissatisfactions were the result of a process of politicization and organization of trade unions and popular movements against the results of macroeconomic adjustment and privatization, and the increase of poverty and inequalities among the "loser" groups in this process (Stiglitz, 2004). The process of privatization and threats to national sovereignty and the weakening of the military elite also played an important role in the erosion of government elites, elements that added to the growing rejection of the management methods and catastrophic results of the neoliberal economy.

It can be said that there was an incipient political reading of the society that the economic model applied by both presidents, Collor and FHC, did not bring them benefits but brought many losses ${ }^{6}$.

The following presidents, Lula da Silva (2003-2010) and Dilma Rousseff (2010-2015), both from the Workers Party-PT, were the first presidents who did not belong to the traditional elites and largely broke with the transnational logic of financialization, secutirization and privatizations, adopting Keynesian economic policies, and the promotion of the internal market and inclusive policies.

\subsubsection{Luis Inácio Lula da Silva, Keynesianism, New Developmentalism and Inclusion}

The 2002 presidential elections took place in a climate of deep crisis, and Lula da

\footnotetext{
"Simultaneously, the process of economic policy, the confrontation with the conservative government, the group losing the strength of neoliberalism, the Washington consensus, the first Collor government and the two (governments) of FHC, the neoliberal theses, the liberalization of the economy, privatization, the reduction of state power, created attrition and dissatisfaction, which facilitated the ascension of a minority group to power." Ricardo Berzoini.
} 
Silva, a left-wing trade union leader, presented himself as a moderate candidate, as a conciliatory and experienced statesman, since he had been a federal deputy several times, and had lost the presidential elections three times in a row. He was elected president for two terms (2003-2006 and 2006-2010) with the highest percentage of popular approval in the history of the country, ending his second term with $87 \%$ approval, an international record. His government was characterized by a coalition of political forces, including some sectors of the right and some of the old oligarchs of traditional elites, such as Sarney and others of the PMDB, which gave him a base of support to approve proposals from the government base. The coalition pact included economic elites and a highly internationalized business class from previous decades. He assumed the government of a failed country, committing himself to govern for all, but especially for the poorest, and for that he established an agreement with the traditional elites, maintained macro-economic equilibrium and created social policies of great social impact, high coverage and transparent management, oriented to results (Anderson, 2011) ${ }^{7}$.

The challenge of the coalition of elites must be understood in an arrogant society that still preserves prejudices of the oligarchic past, of "bachillerismo" (credencialism, or the use of the academic title as a symbol of superiority and nobility) and of racist slavery. Lula was a man whose origins were from extreme poverty, with a low level of formal education, and a trajectory of a union leader who organized the longest-lasting strikes and countless demonstrations of workers and civil society in the country's history during the dictatorship. As a conciliatory leader, he achieved respectability and agreements with businessmen, but he has never been well seen by the military and oligarchic and conservative sectors. On the contrary, he was arrested during the military dictatorship for leading strikes for workers' rights. So, his ability to establish alliances and achieve a coalition pact with broad sectors of the elites is a relevant fact. However, it also aroused hatred and contempt in sectors of traditional elites and, since he was a union leader, he has been accused of corruption - always having to prove his innocence (Santos, 2014; Anderson, 2011).

Almost all the anti-corruption laws and mechanisms in force in the country were implemented during their two governments-the law of transparency in the public service, the law of "clean record" (prohibiting convicted persons from assuming public office), the law of denunciation, and the strengthening of the judiciary power, the public ministry, the Federal Police and the Federal Revenue.

\footnotetext{
7 "We came to power and constituted, in a limited way, a new political elite, a new power arrangement, a command of the Left but one that was forced to seek alliances with the Center, even with the Right to have a minimum of consensus to (implement) the mandate ... (for that reason), our governments never forced a structural confrontation with the Brazilian system, a perverse, patrimonialist and rentier structure, with a regressive tax system, a financial system that-concentrated or not-is always a factor of concentration of wealth and not of distribution of credit. Our land-agrarian structure (of latifundista-esclavista origin) has an aversion to the agrarian reform that has taken place in other capitalist structures during the last 200 years. "Ricardo Berzoini.
} 
It granted them greater investigative, accusation and punishment powers, as well as significant salary increases, with the aim of preventing institutional corruption. The Controladoria Geral da União (CGU), among other control bodies, was created for the first time in Brazil (Anderson, 2011). As a result, between 2003 and 2013, 4577 federal public servants were exposed for various types of irregularities or corruption, and the CGU went on to apply sanctions to companies that committed illicit acts against the state, forbidding them from establishing contracts with the public administration (Ministerio da Transparencia \& CGU, 2014). These measures generated growing dissatisfaction in bureaucracies and in traditional lobbies that sought to interfere in the decisions of the state.

Various social policies with wide coverage were implemented: Fome Zero (Zero Hunger) and support systems for families, BolsaFamília, FarmaciaPopular, SAMU (ambulances), Luz para Todos (Light for All), Cisternas, monetary transfers for the handicapped and elderly, pensions for rural workers, land regulation for Afro-descendant communities (Quilombos) and for landless workers, popular housing, among others. Over the years, the control of inflation, the exit from the crisis, the payment of external debt, investments in infrastructure, full employment and the valorization of the minimum wage above the past annual inflation, combined with the social policies, allowing poverty and inequality-which had been the worst in the world-to be reduced (Bohn, 2017). Likewise, 18 new federal universities, a system of socio-racial quotas, hundreds of Federal Institutes of education and one million comprehensive university scholarships for poor students to attend private universities were created (Anderson, 2011). These inclusive social policies generated great dissatisfaction among the elites and the traditional middle classes, who criticized the use of taxes to maintain social policies and felt that their privileges were being threatened.

The great investment in the growth of the domestic market, through consumption, together with the successful results of the economic and social policy, allowed Lula to be re-elected without confronting the capital or sectors of the democratic center. On the contrary, capital also benefited from economic policy, as well as Center politicians, gained political capital to be re-elected ${ }^{8}$.

The pluralism of interest groups allowed the Executive to be represented in the coalition base, creating a hybrid system and a complex decision-making process that guaranteed governability. In Congress, the coalitions served as a mechanism to extend the debate with the Executive, for the negotiation and inclusion of divergent interests; in this way, it was possible for different groups to gain corporate advantages, mobilize resources and acquire professionalism in ${ }^{8 " T h e ~ L u l a ~ g o v e r n m e n t ~ o c c u p i e d ~ e m p t y ~ s p a c e s ~ v a c a t e d ~ b y ~ t h e ~ i n c o m p e t e n c e ~ o f ~ t h e ~ R i g h t, ~ t h e ~ P S D B, ~}$ in the area of credit expansion, family farming, housing, micro and small business; they changed the relations of the state with society ... the generation of employment was possible because the government took advantage of the favorable conjuncture. For a time, the Right was perplexed, because they had no way to attack us as irresponsible Leftists. Everything was done with a social vision, but it was not Left politics. All this allowed Lula, and later Dilma, to govern even with different interest groups which ended up not fighting because they wanted access to ministries, wanted to be linked to Lula, for his popularity" Ricardo Berzoini. 
political activity and in economic and political agreements.

For several authors it is worth highlighting the fact that groups present different capacities and resources, and pluralism is a political arrangement that recognizes the needs of different groups, allowing them to coexist legitimately. The dispersion of power in interest groups can be an important element for the promotion of rights, for the defense of diverse interests, and for the minimization of the abuse of the power of the state against the citizen (Wedel, 2017; Davis \& Williams, 2017).

Furthermore, other pluralist authors recognize that a political system cannot always deliver satisfactory results for all interest groups, mainly in an environment of indefinite extension of different interests, since the resources available for each group are important to determine access and influence. Thus, institutional structures (the role of government and the degree of openness of systems), political arrangements (coalitions) and the strength of political parties contribute to the political result. During the two governments of Lula and the first of Dilma, satisfactory results were achieved through coalitions and pacts between different interest groups (the coalition pact was to be interrupted by the Opposition in the second government of Dilma Rousseff).

\subsubsection{Dilma Rousseff, Expansion of Rights and Conflicts in the Coalition-Coup d'état}

Dilma Rousseff is an economist who does not belong to the oligarchic elites and followed the economic policy of Lula in her first term (2011-2014), maintaining the macroeconomic balance and, at the same time, creating incentives-the reduction of taxes for entrepreneurs to promote formal employment. The minimum wage also continued to rise above the rate of inflation. She expanded social policies, creating more than 2.5 million units of social housing and more than 2 million scholarships for poor university students. Her government managed to control inflation and expand full and formal employment, and also promoted the creation of the BRICS Bank, a group formed by the emerging countries Brazil, Russia, India, China and South Africa.

Since 2013, the economy has suffered the late effects of the 2008-2009 crisis, such as the drop in commodity prices, creating an opportunity for the Opposition to boycott Congress, rejecting its proposals and approving guidelines that put the economy at risk. She adopted austere measures against the crisis, assigning a financial economist to manage the economy, aggravating the crisis and generating 4 million new unemployed.

It should be noted that Dilma Rousseff had never participated before in elections or political negotiations in the legislative sphere (as was the case of Lula and all the other former presidents of Brazil) and for that she received much criticism that she would not have negotiation skills and encourage political agreements. The growing dissatisfaction of the population, of Congress and of the communication monopolies, allowed the Opposition to divide the coalition base of the government and to approve her impeachment in the Senate in 2016. 
The biggest challenge faced by the government of Dilma was to negotiate the organization, mobilization and political pressure on the part of increasingly numerous social segments, but without experience in collective action to organize their demands and guide them appropriately through the channels of the state in the democratic system. Without knowledge about which level of government, municipal, state or federal should direct their demands, social movements channeled all of them to the Federal Executive: demanding lower taxes, improvements in the quality of education and health, and even higher wage increases. The groups of the extreme Left questioned public works, political connections, the World Cup and the Olympics, protested against an increase of 20 cents in the bus ticket-price in the city of Sao Paulo, and demanded free public transport for the country's entire population; Ultra-conservative groups demanded the return of the military, torture and murder, among many other demands.

The greater the multiplicity of actors, interest groups and demands in the political arena became, the lower was the capacity of the government's elite to respond to these demands and at the same time negotiate economic and political interests in the coalition. As a result, sectors of the elites and popular movements were progressively co-opted by the Opposition.

In the legislature, the new composition of the congress of 2014 favored the lobbies of the conservative elites, particularly the police corporations, the neo-Pentecostal churches and the oligarchical landowners of meat exporters, protectors of the traditional archaic values of past centuries. The caucus of the ruralistas-latifundistas is today the largest lobby in the congress, constituting a quarter of the Chamber of Deputies, and being responsible for great defeats of the government in Congress since 2012. The most powerful interests group in the parliament is looking for the forgiveness of their debts with public banks and the expansion of arable land-indigenous lands mainly in the Amazon region. These differences with the policies of the executive led to a series of vetoes by Dilma to the proposals approved by the rural elite and their allies in Congress. That was the most relevant elite in dispute with the government elite-which prioritized environmental groups and defenders of indigenous groups.

On the other hand, by granting greater power and independence to the controlling bodies, these bureaucratic elites assumed an increasing role in the political decision-making process, together with the media, which convinced society that the president, her party and her allies were corrupt and ignorant. By politicizing their actions, the Federal Police (PF), the Brazilian Intelligence Agency (ABIn), and the Controller-General of the União (CGU) intensified their participation in the Chamber of Deputies (Santos, 2014), and some members of these controlling bodies participated as candidates in the elections, while also accusing and judging their political opponents.

Institutions and bureaucrats began to function as pressure elites with their own interests, generating a new legislative agenda to meet the demands of the ministerial, military, security and judicial bureaucracies, always in search of increased budgets and salaries, more positions, more public competition, more 
autonomy, and more power to punish and control over other powers and organs. All these decisions depend on the approval of the Legislative, exponentially multiplying the disputes between the interests of specific sectors of the Legislature and the Executive, and society's other interest groups. All decisions depend on the final approval or veto of the executive, putting more pressure on the veto power of the president and increasing their political erosion, empowered by communications monopolies ${ }^{9}$.

This competition among elites adds to the greater partisan fragmentation of the government coalition and its alliance with the conservative opposition, which did not accept its defeat in the elections and seized the opportunity of the crisis and hardship of the elites in the government ${ }^{10}$.

In addition to these national tendencies, the links of the different elites with international interest groups are also narrowing. The processes of financialization, globalization and deregulation of economies allowed the formation of power groups parallel to governments, bringing together officials, advisers and lobbyists from different countries, transnational companies and financial systems that threaten democracy and accountability-even in developed countries. They are dense, self-operating, informal and flexible collaboration networks of trusts that establish common goals, coordinating their efforts inside and outside official structures (Weel, cited by Wedel, 2017). Their actions are not transparent, but they reach a high level of influence, in contrast to the command posts of national governments, which do have to provide accounts and follow complex rules of control and transparency (Wedel, 2017; Davis \& Williams, 2017).

The networks of transnational elites operate with cohesion and are based on shared conviction and action, they are fervent defenders of deregulation and privatization. They have a pool of resources and their members change and overlap various roles, in government, in business, in non-governmental organizations and in the media. They keep exclusive access to state information and leak it to the media. The public, without basic information, is unable to judge the issues for themselves. These networks, known in Europe as The Locomotives, accumulate official information and dominate the construction of images for society as a whole (Wedel, 2017).

\footnotetext{
${ }^{9}$ With Dilma, this relationship is deteriorating, these sectors begin to get on the defensive, due to several factors. the crisis of 2014, the demonstrations of 2013, which were planned to put all the (political) waste on the federal government, but with demands that are not federal; the parliamentary conjuncture, where a group of opportunists, adventurers and corrupt people formed a large block in parliament to blackmail the government. A large movement was created in the media, in the economic sector, and in the judiciary, which was isolating us politically. Ricardo Berzoini.

10" This new political elite that homogenized (the Congress) from 2003 to 2016 lost strength as this parliamentary, media and non-elected articulation advanced within the state, (there are) more factors that generated perplexity, together with the lack of capacity of the government to face that offensive on the Right. The judicial (power) already came before, before the AP470 (first corruption process against the PT and its allies, 2005), forcefully, but we managed to answer and dispute the narrative. In the second phase, we managed to reverse a little the slaughter that the lava-jato (anti-corruption operation) had initiated..., an avalanche of brutal news, the inability to have a means of communication and to respond." Ricardo Berzoini.
} 
The conformation of these international networks, which operate invisibly and without transparency, did not go unnoticed in the political evaluation of the new progressive elites, but the speed of events was surprising ${ }^{11}$.

This description explains the actions of the elites of the judiciary power, of the Public Ministry, of the Federal Police of Brazil, always articulating with the media to filter suspicions, accusations and actions related to the investigations of the corruption processes, but exclusively against the parties in the situation, never those in opposition. The communication media monopolies always arrive at incidents before the Federal Police, search warrants and the apprehension of goods and those accused of alleged anti-corruption. They are reality television shows in which reporters behave as accusers and judges, legitimizing and promoting all kinds of abuse of authority, illegalities and unconstitutionalities, such as delaying deadlines, confining evidence and rewarding confessed criminals with money and reduction of sentences, and the prescription of processes against the elites of opposition parties and their allies and advisers. At the same time, processes and investigations are expedited, false evidence is created, illegal recordings are made, illegal "preventive" arraignments are performed and there is daily media publicity against the members and leaders of government elites and their allies, promoting even more divisions in the coalition base.

The results of these investigations and accusations were not only the weakening of the party and government leaders, but also of the public companies that are in the line for privatization under the current government and of the large national private companies and, recently, the weakening of the same judiciary power of the public prosecutor and of the Federal Police (surveys showing that the population distrusts more and more the impartiality of these organs). This political and institutional erosion was aggravated when these public officials pressed the Executive and the Legislature to grant them a $41 \%$ salary increase and other illegal benefits-demands that had been systematically rejected by Lula, Dilma Rousseff and the party's caucus in Congress, because acceding to such demands would have had a devastating impact on the public budget.

Another interest group that had been ignored during the entire period of Lula and Dilma's governments was the military, who had lost control of the Ministry of Defense at the end of the FHC government in 1998. The armed forces had also benefited from the new progressive elites, in terms of budgets and institutional strengthening. However, at the time of the crisis of 2014, this group also did not accept limitations in their budgets and increased their demands and dissa-

11"Has it been orchestrated? It was difficult to appear spontaneous, because the opposition in Brazi had no political force to make that mobilization. The opposition forces perceived the opportunity to take advantage, because these movements had no flags, in the beginning, it was an attempt to awaken people's dissatisfactions in such an unequal Brazil, in the quality of life. But there were already the experiences of Honduras, Paraguay, and Brazil, where this happens every couple of years or so. Since 2004, we have advanced a lot in foreign policy (BRICS, and the BRICS bank) and Brazil s actions on international policy issues with countries that are out of line with the United States could be seen as a threat to the US s leading role. Brazil and Russia have always been important, but China is now a superpower. On the domestic side, Lula is being punished for the transparency laws he created, which led to the exposition of more than 5000 corrupt public officials." Ricardo Berzoini. 
tisfactions with the government, leading to the division of the coalition and the impeachment of Dilma; the presidency was assumed by the vice-president.

Upon assuming the presidency, Michel Temer, a politician of long experience, resumed the liberal agenda, and took measures that aggravated the economic crisis and tripled unemployment. He froze the public budget for 20 years, and initiated the process of privatization of the oil, energy and water industries, as well as plunging the entire social sector into a state of crisis. With the loss of popularity and the 2018 elections approaching, he recently had to undertake a military intervention in Rio de Janeiro and the creation of a Ministry of Defense for the military; these are his last resources to legitimize and hold on to power, in the face of the serious economic and political crisis, as well as a series of corruption investigations against him.

\section{Discussion}

Brazil has a history of four centuries of colony and empire. Thirty years of a Republic, similar to that of a patronized Roman slaveholder regime, ended with a military coup and twenty years of bureaucratic dictatorship, followed by ten years of democracy collapsing after a moralizing military coup, 21 years of military dictatorship, 26 years of democracy interrupted by a moralizing blow and, finally, the current ruling elites seeking to legitimize themselves with a partial and moralizing military intervention.

The young Brazilian democracy lacks legitimacy and appreciation on the part of its elites and its "non-people", that is, of a mass population disempowered by slavery, poor education, without moral values (according to its elite) and thus incapable to make decisions about the country, being historically defined by intellectuals as "bestialized" (Carvalho, 2003).

The oligopolistic and patrimonial elites led this secular cycle that alternated between long dictatorships, short democracies, and moralizing coups; the new emerging elites, strengthened by democracy: businessmen, military, bureaucrats, and high school graduates, reproduced their values, aristocratic practices and methods of family inheritance, patrimonialism, autocracy and exclusivity to reposition themselves in national and international markets and in State institutions. It was thus that the Brazilian elites delayed the end of slavery, industrialization, capitalism and modernity in Brazil, manipulating the population with moralistic arguments and deceiving the elites of the most developed countries, while giving absolute priority to the rapid enrichment of their family group and its loyalty networks.

In a time of globalization and internationalization of financial markets, the traditional Brazilian elites were inserted into global networks to exercise power over institutions and national political and economic decisions; supporting efforts for the fragmentation of national governments and democracy itself, they supported and promoted coups to maintain and multiply their privileges and their power of absolute decision within the country. They refused to make an 
effort for democratic coexistence and to build a society with strong republican institutions. Instead, they ignored the rule of law, democracy, options and demands of all other segments of society, which they considered inferior.

The history of the elites in Brazil, observed through the dramatic events of the cycle of long dictatorships alternating with short lapses of democracy, was then interrupted by new moralizing blows, almost always abusing the indignant response to corruption that, they supposed, would be exclusive to the representatives elected by direct vote and from the same people, but never from the elites. This repetitive and selective moralizing trend suggests that the Brazilian oligarchic elites are guided by a feeling of superiority, which would enable them, exclusively, to lead a "lower" majority mass morally, socially and intellectually and would therefore not be able to acquire the capacities to self-determine and decide how it prefers to organize itself as a society.

This repetition of the typical cycle of dictatorship-attrition-democracy-moralizing coup to "put an end to corruption" corroborates Darcy Ribeiro's thesis that, in Brazil, a democratic system has not yet been consolidated but, instead, a system similar to that of a patronized Roman slave-ownership exists, led by autocratic elites who judge themselves to be a family hereditary nobility. The maximum value of these elites is patrimonialism, the search for opportunities and easy and quick enrichment exclusively for their relatives and friends, who would be the only bearers of a supposed moral superiority with respect to the governed majority, and this would need to be tutored and, eventually, corrected, for not having the capacity to make decisions and correctly elect their representatives.

Only since 1988, scarcely 30 years ago, has Brazil become a mass democracy in which the majority of the population acquired the right to vote directly and elect their own representatives. The patrimonial and exclusivist elites participated in the recent re-democratization process and were able to choose and associate with global interests and to implement the measures proposed by the Washington Consensus. However, they were rejected by direct vote and excluded from real power for 13 years, during which they were replaced, for the first time, by persons alien to their lineages and independent of their control. They were surprised to see the economy and democracy, not only work, but strengthen. It was impossible for them to understand how and why these inferior and ignorant non-people were unable to recognize the natural superiority of the exceptional and exclusive elites, and assumed the risk of opting for politicians without "pedigree", without the supposed intellectual and moral superiority that the elites assigned to them.

\section{Conclusion}

In Brazil, the secular repetition of the dictatorship-attrition-democracy-coupmoralizing cycle has an educational component: it prevents society from valuing and developing an appreciation for dialogue, agreements and tolerance, for the rule of law and human rights, understanding and adhering to a democratic con- 
stitutional pact, at the same time training itself to feel fear and immobilizing itself in the face of every threat, repeating every anti-corruption war cry, a corruption that is only of the inferior people and their also inferior elected representatives, a cry that is released after every ten or twenty years of democratic encouragement.

The new actors of civil society are just beginning to develop their first experiences on the longest democratic functioning period in history, only 30 years, but still have impregnated with elitist values, speeches of false-moralistic indignation and incentives for infinite demands oriented exclusively to the Executive branch, the only one that is still controlled by popular scrutiny-as if the historical backwardness of these multiple demands were the exclusive responsibility of the short democratic periods and their elected leaders.

Thus, it interests the aristocratic elites to multiply their own demands in democratic times, taking advantage of the benefits of democracy to overcome their own difficulties and limitations when negotiating their interests in the field of politics and agreements between equals, professionalizing and learning appropriate experiences and knowledge developed in democratic periods, along with the democrats, and thus jumping to international organizations and large transnational corporations as "experts" in democracy, in democratic policies, in the fight against poverty and inequality and in the success of the economy.

For that reason, they admit to opening short democratic windows in which they are strengthened as much as possible and co-opt new secondary elites and the middle classes, enriched by democratic development. In fact, the emerging elites of bureaucrats from state institutions and top executives in business elites who come out of the strengthened, autonomous, well-trained and well-financed democratic periods, are, in the majority, heirs of an autocratic patriarchy, descendants of elitist oligopolies that have accumulated patrimonial, elitist and corporate values throughout the century. After taking advantage, they close these democratic windows with blows that leave lessons that are moralizing, discriminating and humiliating to both electors and the elected, reaffirming their superiority and fear from their perceived inferiors.

This scenario was the backdrop to the increase in competition between traditional oligopolistic elites, who previously managed to establish exclusive pacts without taking into account the demands of society, in a country where new financial, business, military, bureaucratic elites are multiplying, but now also the unions, social movements and independent parties of the elites, are committed to the majority of the population.

The trans-nationalization of the financial and business elites and their infiltration into the state, in the executive and legislative branches, generates demands that cannot be met, and therefore, dissatisfactions without a negotiated solution are factors that were vanquished by the loss of popularity of Dilma Rousseff, for the rupture of her coalition base and for her impeachment. And the lack of response from the progressive elites in the government is due, rather, to a difficul- 
ty in fully understanding these processes of internationalization and conditions to prepare and coordinate, in the face of an accelerated avalanche of information and unprecedented actions of the national and international elites.

\section{Conflicts of Interest}

The authors declare no conflicts of interest regarding the publication of this paper.

\section{References}

Anderson, P. (2011). Lula's Brazil. London Review of Books, 33, No. 7.

Babb, S. (2001). The Rise of the New Money Doctors in Mexico. In Conference on the Financialization of the Global Economy, Political Economy Research Institute (PERI) (pp. 32). Amherst, MA: University of Massachusetts at Amherst.

Belieiro Junior, J. C. M. (2008). Politica e economia no governo FHC: A questão dos economistas (Vol. 2, pp. 185-203). Topos. Universidade Estadual Paulista, UNESP.

Best, H., \& Cotta, M. (2000). Between Professionalisation and Democratisation: A Synoptic View on the Making of the European Representative. In Heinrich Best and Maurizio Cotta, Parliamentary Representatives in Europe 1848-2000. Legislative Recruitment and Careers in Eleven European Countries (pp. 493-526). Oxford: Oxford University Press.

Bohn, S. (2017). Quasi-Post-Neoliberal-Brazil. Social Change amidst Elite Adaptation and Metamorphosis. In L. L. North, \& T. D. Clark (Eds.), Dominant Elites in Latin America: From Neo-Liberalism to the "Pink Tide" (pp. 57-62). London: Latin America Political Economy, Library of the Congress.

Bottomore, T. (1995). Elites y Sociedad. Editora Talasa. Asturias.

Bresser-Pereira, L.C. (1992). O decimo-primeiroplano de estsabilizacao. In J. P. R. Veloso (Ed.), Combate a Inflacao e Reforma Fiscal (pp. 132-150). Rio de Janeiro: José Olympio.

http://www.bresserpereira.org.br/papers/1991/88.DecimoPrimeiroPlanoMarcilio.pdf

Carvalho, J. M. (2003). Os Bestializados-O Rio de Janeiro e a República que nãofoi. Sao Paulo: Compania das Letras.

Cesário, P. S. (2016). Redes de influência no Congresso Nacional: Como se articulam os principais grupos de interesse. Revista de Sociologia e Política, 24, 109-127.

http://www.scielo.br/scielo.php?script=sci_arttext\&pid=S0104-44782016000300109\&ln $\mathrm{g}=\mathrm{en} \& \mathrm{nrm}=\mathrm{iso}$

Chaia, V. (2010). A longa conquista do voto na história política brasileira. Textos. PUC-SP FUNDASP. CNPq. Sao Paulo.

http://www4.pucsp.br/fundasp/textos/downloads/O_voto_no_Brasil.pdf

Codato, A. (2015). Estado Novo no Brasil: Um Estudo da Dinâmica das Elites Políticas Regionaisem Contexto Autoritário DADOS. Revista de Ciências Sociais, Rio de Janeiro, 58 , No. 2.

Davis, A., \& Williams, K. (2017). Introduction: Elites and Power Alter Financialization. Theory, Culture \& Society, 34, 3-26.

Davatz, T. (1850). Memorias de um colono no Brasil. Sao Paulo: Livraria Martins.

D’Araujo, M. C. (2001). A Era Vargas dos anos 1930 aosanos 1950. En Pereira, Paulo Roberto (org.) Brasiliana da Biblioteca Nacional, Editora Nova Fronteira y Biblioteca Nacional. Rio de Janeiro. 
Fernandes, F. (2008). Aintegracão do negro nasociedade de classes: O legado da "racabranca"(Vol. 1, 5th ed.). São Paulo: Globo.

Freire, A., \& Penna, L. (2001). Primeira República: Os Estados Unidos do Brasil. In P. R. Pereira (Ed.), Brasiliana da Biblioteca Nacional, Editora Nova Fronteira y Biblioteca Nacional (pp. 285-296). Rio de Janeiro: Fundacao Biblioteca Nacional, Nova Fronteira.

Hsieh, H. F., \& Shannon, S. E. (2005). Three Approaches to Qualitative Content Analysis. Qualitative Health Research, 15, 1277-1288.

Lipset, S. M. (1967). Values, Education and Entrepreneurship. In S. M. Lipset, \& A. Solari (Eds.), Elites in Latin America (pp. 3-60). New York, NY: Oxford University Press.

Lopez, M. (2013). Elite Theory. Sociopedia ISA. Interdisciplinary Network for Studies of Social Inequality (NIED). Rio de Janeiro: The Federal University of Rio de Janeiro.

Mills, C. W. (1956). La elite delpoder. Fondo de Cultura Económica, México, (e.o., 1956/1987) (pp. 12-18).

Milner, J. M. (2015). Elites. A General Model. Cambridge: Polity Press.

Ministerio da Transparencia \& CGU. (2014). Brasilia.

http://www.cgu.gov.br/sobre/institucional/ministro/artigos/combate-a-corrupcao-no-g overno-lula

Missiato, V. A. R. (2011). A Construcão da Relacão Civil-Militar no governo FHC: O Olhar de Homens da Caserna. In Anais do XXVI Simposio Nacional de Historia (p. 14). São Paulo: Universidade de São Paulo.

Mourão, R. P. (2012). Desenvolvimento, industrializacão e ordenamentopolítico: ordenamento politico: Uma discussao sobre o estado sem Getulio Vargas e Juscelino Kubitschek dois Estados, uma “Ordem”. Revista Historia em Curso, 2, No. 2. http://periodicos.pucminas.br/index.php/historiaemcurso/article/view/1866

Pakulski, J. (2018). The Development of Elite Theory. In H. Best, \& J. Higley (Eds.), The Palgrave Handbook of Elite Theory (pp. 9-16). London: Palgrave MacMillan.

Ribeiro, D. (1976). Tipología Política Latinoamericana. El fascismoen América. Nueva Política, No. 1, 85-106.

Saez, M. A. (2004). Partidospolíticosen América Latina: Precisiones conceptuales, estado actual y retosfuturos. Revista Je EstudiosPoliticos, No. 124, 55-94.

Santos, M. L. (2014). Representacao de interesesna arena legislativa: Osgrupos de pressaonaCamara de Deputados (1983-2012). Texto para discussão, Rio de Janeiro: Instituto de Pesquisa Econômica Aplicada.

Schwarcz, L. M. (2001). O Brasil Imperial: D. Pedro II e o Século XIX. In P. R. Pereira (Ed.), Brasiliana da Biblioteca Nacional, Editora Nova Fronteira y Biblioteca Nacional (pp. 251-266). Rio de Janeiro: Fundacao Biblioteca Nacional Nova Fronteira.

Stiglitz, J. (2004). Los felices 90: La semilla de la destrucción. Trad. V. Gordo y M. Ramírez. Madrid: Taurus.

Wedel, J. R. (2017). From Power Elites to Influence Elites: Resetting Elite Studies for the 21st Century. Theory, Culture \& Society, 34, 153-178.

World Bank (2016). Brazil Overview. http://www.worldbank.org/en/country/brazil/overview 